\title{
New and improved determinations of velocity of Ice Streams B and C, West Antarctica
}

\author{
I. M. WHILLANS \\ Byrd Polar Research Center and Department of Geological Sciences, The Ohio State University, Columbus, Ohio 43210, U.S.A. \\ C.J. VAN DER VEeN \\ Byrd Polar Research Center, The Ohio State University, Columbus, Ohio 43210, U.S.A.
}

\begin{abstract}
Measurements of velocity have been made on and next to Ice Streams B and C, West Antarctica. The results are more precise than previous work and constitute a $93 \%$ increase in the number of values. These velocities are used to describe the confluence of flow into the ice streams and the development of fast icestream flow. The onset of fast-streaming flow occurs in many separate tributaries that coalesce down-glacier into the major ice streams. For those inter-stream ridges that have been studied, the flow is consistent with steady state. Along Ice Stream B, gradients in longitudinal stress offer little resistance to the ice flow. The transition from basal-drag control to ice-shelf flow is achieved through reduced drag at the glacier base and increased resistance associated with lateral drag. Velocities in the trunk of Ice Stream $\mathrm{C}$ are nearly zero but those at the up-glacial head are similar to those at the head of Ice Stream B.
\end{abstract}

\section{BACKGROUND}

The reason for the differences in flow regime in West Antarctica (fast-streaming flow and nearly stagnant ridges), as well as for the recent stoppage of Ice Stream C, are still largely unknown. Streaming flow is not an isolated phenomenon, for analyses of aerial photography and SPOT imagery show that the up-glacial onset of ice streaming occurs over a broad zone (Vornberger and Whillans, 1986, 1990; Merry and Whillans, 1993). Moreover, the shear margins can be traced over large distances. Once started, ice streams seem to be able to maintain their characteristics.

Field programs were initiated on Ice Streams B and C (Fig. 1), with the objective of testing the early inferences about the presence, extent and steadiness of ice streams, and to infer the mechanics controling their motion. Ice Stream $\mathrm{C}$ was selected for study because of the indications that it had stopped flowing. Studies were conducted on Ice Stream B because it is active, has a simpler basal topography than other ice streams, but otherwise seems representative of most of the ice streams. Also, being next to the stopped Ice Stream C, it too may be changing, perhaps through capture of the drainage of Ice Stream C.

Because both Ice Streams B and C appear to be undergoing significant change, understanding their mechanics is crucial. To address this issue, surface velocities were measured on a local scale (by deploying strain grids: Whillans and Van der Veen, 1993), on a regional scale (from repeat aerial photography: Whillans and Bindschadler, 1988; Whillans and others, 1993), and on a large scale covering the entire ice stream and its catchment area. These large-scale velocities were determined by repeat occupation of Doppler satellite-tracking stations. The present contribution presents and discusses results of the large-scale survey of the ice streams. Preliminary results of many velocity determinations have been given in Whillans and others (1987), but the velocities presented here are more precisely determined and many additional measurements are included.

\section{METHODS}

Poles were placed vertically in the surface of the ice sheet and surveyed on at least two occasions for position. The resulting vectors for surface velocity are presented in Table 1 and plotted in Figures 2 and 3. The base map for Figure 2 includes the major geographic features mapped from aerial photographs (Vornberger and Whillans, 1990), satellite imagery (Merry and Whillans, 1993), as well as features on satellite imagery additional to those discussed by Merry and Whillans. Figure 3 shows velocity vectors together with elevation contours and the boundaries to the ice streams.

The surveying was done using Transit (also called "Doppler") satellite receivers. Most of the equipment were Magnavox model 1502 "Geoceivers", which were left tracking at each site for about $24 \mathrm{~h}$. As described in McDonald and Whillans $(1988,1992)$, the data are reduced using precise, post-processed orbits for the satellites, or else they are linked in a network adjustment to other sites with positions so obtained. The earlier 
Table 1. Positions and horizontal velocities of stations. Positions are in the WGS84 system. Velocity components are parallel to, and in the direction of $90^{\circ} \mathrm{W}$ longitude (grid west) and $180^{\circ}$ longitude (grid south). The last column indicates how much the more precisely determined ice speed differs from the values tabulated in Whillans and others (1987) (values that are new are so indicated)

\begin{tabular}{|c|c|c|c|c|c|c|c|c|c|c|}
\hline \multirow[t]{2}{*}{ Station } & \multicolumn{3}{|c|}{$\begin{array}{l}\text { South } \\
\text { latitude }\end{array}$} & & $\begin{array}{c}\text { Wes } \\
\text { longit }\end{array}$ & & $\begin{array}{c}\text { Ellipsoidal } \\
\text { height }\end{array}$ & & ity & $\begin{array}{l}\text { Correction } \\
\text { to previous value }\end{array}$ \\
\hline & 0 & ' & $"$ & 0 & ' & " & $\mathrm{m}$ & south & $a^{-1}$ west & $\mathrm{ma}^{-1}$ \\
\hline $\mathrm{UpB}_{\mathrm{p}-01}$ & 83 & 28 & 50.218 & 138 & 11 & 57.763 & 339.0 & 208.9 & -389.5 & -1.0 \\
\hline 11 & 84 & 02 & 9.357 & 135 & 58 & 26.172 & 393.9 & 319.4 & -184.2 & -1.3 \\
\hline 12 & 83 & 51 & 28.424 & 135 & 51 & 29.414 & 398.6 & 19.3 & -19.6 & -0.5 \\
\hline 13 & 83 & 41 & 9.329 & 136 & 20 & 18.413 & 400.4 & 56.0 & -104.5 & 0.6 \\
\hline 14 & 83 & 24 & 37.414 & 136 & 40 & 57.989 & 365.9 & 221.5 & -360.8 & -0.6 \\
\hline 15 & 83 & 13 & 36.882 & 136 & 44 & 12.973 & 389.6 & -2.2 & -5.9 & 2.3 \\
\hline $\begin{array}{l}16 \\
17\end{array}$ & $\begin{array}{l}84 \\
83\end{array}$ & 04 & 52.615 & 137 & 25 & 53.826 & 369.0 & 18.5 & 1.2 & -4.5 \\
\hline $\begin{array}{l}17 \\
19\end{array}$ & $\begin{array}{l}83 \\
83\end{array}$ & 52 & 17.069 & 137 & 55 & 6.098 & 352.2 & 322.8 & -177.0 & 8.1 \\
\hline $\begin{array}{l}19 \\
21\end{array}$ & $\begin{array}{l}83 \\
83\end{array}$ & 16 & 21.976 & 138 & 15 & 56.961 & 357.8 & -3.8 & -7.5 & 3.4 \\
\hline $\begin{array}{l}21 \\
22\end{array}$ & $\begin{array}{l}83 \\
83\end{array}$ & 34 & 44.792 & 138 & 5 & 48.825 & 347.1 & 1.4 & -0.6 & New \\
\hline $\begin{array}{l}22 \\
24\end{array}$ & $\begin{array}{l}83 \\
83\end{array}$ & 26 & 30.460 & 140 & 40 & 22.154 & 306.1 & 162.4 & -431.5 & -4.0 \\
\hline $\begin{array}{l}24 \\
25\end{array}$ & $\begin{array}{l}83 \\
83\end{array}$ & 24 & 6.683 & 141 & 59 & 56.347 & 310.7 & -4.5 & -4.3 & New \\
\hline $\begin{array}{l}25 \\
26\end{array}$ & $\begin{array}{l}83 \\
83\end{array}$ & 39 & $\begin{array}{l}36.546 \\
17.970\end{array}$ & 143 & 34 & 36.104 & 278.4 & 327.3 & -659.5 & 5.3 \\
\hline 27 & $\begin{array}{l}83 \\
83\end{array}$ & $\begin{array}{l}27 \\
38\end{array}$ & $\begin{array}{l}17.970 \\
40.412\end{array}$ & $\begin{array}{l}143 \\
139\end{array}$ & 54 & 1.193 & 292.2 & $\begin{array}{r}-5.5 \\
5.0\end{array}$ & $\begin{array}{l}-5.0 \\
-0.9\end{array}$ & 2.4 \\
\hline 31 & 83 & 56 & $\begin{array}{l}40.412 \\
35.687\end{array}$ & $\begin{array}{l}139 \\
142\end{array}$ & 49 & 37.307 & & $\begin{array}{l}5.0 \\
1.0\end{array}$ & $\begin{array}{l}-0.9 \\
-3.6\end{array}$ & -4.9 \\
\hline 32 & 84 & 00 & 51.738 & $\begin{array}{l}142 \\
144\end{array}$ & $\begin{array}{l}24 \\
26\end{array}$ & $\begin{array}{r}57.575 \\
5.960\end{array}$ & $\begin{array}{l}321.7 \\
212.4\end{array}$ & $\begin{array}{l}1.0 \\
4.3\end{array}$ & $\begin{array}{l}-3.6 \\
-5.9\end{array}$ & -2.3 \\
\hline 33 & 83 & 45 & 42.209 & 145 & $\begin{array}{l}26 \\
40\end{array}$ & $\begin{array}{r}5.960 \\
18.436\end{array}$ & $\begin{array}{l}212.4 \\
212.2\end{array}$ & $\begin{array}{r}4.3 \\
-15.2\end{array}$ & -824.4 & $\begin{array}{r}1.3 \\
-2.5\end{array}$ \\
\hline 34 & 83 & 35 & 4.069 & 146 & 14 & 38.294 & 231.0 & -5.9 & -3.6 & $\begin{array}{r}-2.5 \\
2.9\end{array}$ \\
\hline 41 & 84 & 04 & 41.549 & 144 & 58 & 3.863 & 150.8 & 3.6 & -7.7 & $\begin{array}{r}2.9 \\
-0.5\end{array}$ \\
\hline $\begin{array}{l}42 \\
43\end{array}$ & 83 & 54 & 53.514 & 146 & 46 & 5.538 & 195.6 & -237.1 & -760.5 & $\begin{array}{r}-0.5 \\
3.6\end{array}$ \\
\hline $\begin{array}{l}43 \\
44\end{array}$ & 83 & 44 & 30.623 & 148 & 10 & 40.563 & 186.5 & -4.3 & -8.8 & 7.8 \\
\hline $\begin{array}{l}44 \\
45\end{array}$ & $\begin{array}{l}84 \\
84\end{array}$ & 14 & 10.822 & 146 & 11 & 47.666 & 142.1 & 6.5 & -18.2 & 2.3 \\
\hline $\begin{array}{l}45 \\
46\end{array}$ & $\begin{array}{l}84 \\
83\end{array}$ & 04 & 59.908 & 148 & 9 & 50.515 & 140.9 & -172.1 & -697.4 & -2.7 \\
\hline $\begin{array}{l}46 \\
47\end{array}$ & $\begin{array}{l}83 \\
83\end{array}$ & 51 & 48.236 & 149 & 36 & 23.101 & 150.5 & -2.9 & -2.8 & 1.0 \\
\hline $\begin{array}{l}47 \\
51\end{array}$ & $\begin{array}{l}83 \\
82\end{array}$ & 56 & 7.612 & 147 & 59 & 8.833 & 154.4 & -225.5 & -756.0 & 0.9 \\
\hline $\begin{array}{l}51 \\
52\end{array}$ & $\begin{array}{l}82 \\
83\end{array}$ & 51 & 11.614 & 131 & 31 & 40.767 & 555.3 & -2.8 & -9.0 & 5.4 \\
\hline $\begin{array}{l}52 \\
53\end{array}$ & $\begin{array}{l}83 \\
83\end{array}$ & 10 & 43.800 & 132 & 42 & 44.441 & 431.5 & 93.3 & -160.4 & 2.6 \\
\hline $\begin{array}{l}53 \\
54\end{array}$ & $\begin{array}{l}83 \\
83\end{array}$ & 02 & 11.953 & 129 & 49 & 20.592 & 537.6 & 35.8 & -46.8 & 3.9 \\
\hline 55 & $\begin{array}{l}83 \\
83\end{array}$ & 13 & 54.004 & 130 & 40 & 11.288 & 498.6 & 72.9 & -60.0 & New \\
\hline 56 & 83 & $\begin{array}{l}17 \\
35\end{array}$ & $\begin{array}{l}33.645 \\
43.035\end{array}$ & $\begin{array}{l}128 \\
131\end{array}$ & $\begin{array}{l}44 \\
47\end{array}$ & $\begin{array}{l}6.978 \\
8.727\end{array}$ & 582.7 & 109.4 & -46.2 & -5.2 \\
\hline 57 & 83 & $\begin{array}{l}30 \\
33\end{array}$ & $\begin{array}{l}43.035 \\
46.359\end{array}$ & $\begin{array}{l}151 \\
129\end{array}$ & $\begin{array}{l}41 \\
21\end{array}$ & $\begin{array}{r}8.727 \\
39.201\end{array}$ & 499.9 & 34.3 & -7.4 & 0.1 \\
\hline 58 & 83 & 54 & 14.171 & 133 & 28 & $\begin{array}{l}39.201 \\
30.046\end{array}$ & 586.0 & 37.1 & $\begin{array}{r}-9.1 \\
-136\end{array}$ & -0.8 \\
\hline 59 & 84 & 04 & 12.899 & 129 & 20 & $\begin{array}{l}30.046 \\
17.973\end{array}$ & 487.0 & & $\begin{array}{l}-13.6 \\
-57.4\end{array}$ & $\begin{array}{l}1.0 \\
0.0\end{array}$ \\
\hline 60 & 84 & 09 & 56.938 & 130 & 27 & $\begin{array}{l}17.973 \\
46.306\end{array}$ & $\begin{array}{l}795.7 \\
720.0\end{array}$ & $\begin{array}{r}157.9 \\
59.3\end{array}$ & $\begin{array}{l}-57.4 \\
-45.2\end{array}$ & $\begin{array}{l}0.0 \\
1.6\end{array}$ \\
\hline 61 & 82 & 52 & 57.814 & 132 & 32 & $\begin{array}{r}46.306 \\
9.426\end{array}$ & $\begin{array}{l}720.0 \\
514.5\end{array}$ & $\begin{array}{r}59.3 \\
-0.3\end{array}$ & & ${ }^{1.6}$ \\
\hline 63 & 83 & 03 & 55.984 & 131 & 35 & 24.007 & $\begin{array}{l}514.3 \\
465.7\end{array}$ & 42.7 & -90.5 & $\begin{array}{l}\text { New } \\
\text { New }\end{array}$ \\
\hline 64 & 83 & 10 & 18.042 & 129 & 2 & 5.250 & 562.5 & 26.5 & -9.6 & $\begin{array}{l}\text { New } \\
\text { New }\end{array}$ \\
\hline 65 & 83 & 24 & 26.562 & 129 & 38 & 31.445 & 540.1 & 101.9 & -81.3 & $\begin{array}{l}\text { New } \\
\text { New }\end{array}$ \\
\hline 71 & 83 & 33 & 21.238 & 136 & 27 & 2.727 & 391.7 & 2.9 & -0.4 & $\begin{array}{r}\text { New } \\
-6.1\end{array}$ \\
\hline 72 & 83 & 40 & 57.426 & 137 & 59 & 27.890 & 379.8 & 1.1 & -1.3 & $\begin{array}{l}-0.1 \\
-9.3\end{array}$ \\
\hline 80 & 82 & 22 & 4.214 & 136 & 56 & 15.783 & 459.1 & 1.8 & -0.4 & -3.2 \\
\hline 81 & 82 & 36 & 39.659 & 137 & 18 & 27.350 & 465.2 & 1.3 & -6.5 & New \\
\hline 82 & 82 & 21 & 31.201 & 136 & 20 & 17.101 & 492.5 & 1.4 & -1.9 & New \\
\hline 83 & 82 & 09 & 8.329 & 136 & 19 & 5.263 & 498.9 & 8.3 & -9.6 & New \\
\hline 90 & 82 & 22 & 12.047 & 135 & 41 & 22.330 & 545.1 & 5.0 & -9.2 & 4.5 \\
\hline 100 & 82 & 21 & 9.148 & 130 & 47 & 36.346 & 639.1 & 27.1 & -10.9 & New \\
\hline 101 & 82 & 36 & 49.614 & 128 & 44 & 9.657 & 706.2 & 40.1 & -36.0 & New \\
\hline 110 & 82 & 07 & 13.321 & 128 & 27 & 6.071 & 715.8 & -167.4 & -741.2 & New \\
\hline 133 & 82 & 19 & 19.603 & 119 & 45 & 26.473 & 896.1 & -85.2 & -349.9 & New \\
\hline 330 & 83 & 25 & 59.830 & 137 & 17 & 39.660 & 347.9 & 219.8 & -374.0 & 8.5 \\
\hline $422^{(1)}$ & 83 & 28 & 35.953 & 122 & 32 & 10.591 & 882.7 & 10.9 & -1.9 & New \\
\hline NORTH & 82 & 53 & 31.509 & 136 & 39 & 36.974 & 511.1 & -1.0 & -3.2 & 0.4 \\
\hline SOUTH & 84 & 29 & 48.710 & 134 & 16 & 48.940 & 664.1 & 12.1 & -3.5 & -4.4 \\
\hline A19275 (2) & 84 & 24 & 26.418 & 154 & 42 & 20.699 & 95.5 & 207.5 & 35.2 & New \\
\hline $\mathrm{B} 17-18^{(2)}$ & 83 & 56 & 57.925 & 153 & 35 & 40.723 & 81.3 & 242.2 & -340.4 & New \\
\hline $\mathrm{B} 25^{(1)}$ & 83 & 52 & 1.899 & 153 & 10 & 38.430 & 90.8 & -2.9 & 5.0 & New \\
\hline $\mathrm{C} 4^{(2)}$ & 84 & 57 & 49.689 & 165 & 38 & 31.862 & 207.1 & -1.2 & -3.9 & New \\
\hline $\operatorname{CIR}^{(1)}$ & 83 & 37 & 8.349 & 166 & 45 & 15.696 & 46.8 & 214.6 & -111.7 & New \\
\hline $\mathrm{DNB}^{(2)}$ & 84 & 10 & 26.853 & 154 & 21 & 16.687 & 85.4 & 246.3 & -433.3 & New \\
\hline E2-LP1 ${ }^{(1)}$ & 83 & 00 & 4.751 & 172 & 59 & 52.329 & 84.7 & -16.1 & 10.9 & New \\
\hline E2.3 $3^{(1)}$ & 83 & 33 & 5.442 & 168 & 13 & 13.498 & 35.9 & 126.7 & -102.1 & New \\
\hline $\mathrm{E} 3^{(\mathrm{i})}$ & 83 & 22 & 44.910 & 169 & 34 & 27.758 & 36.8 & -7.3 & -1.4 & New \\
\hline $\mathrm{E} 4^{(2)}$ & 83 & 09 & 20.176 & 171 & 36 & 37.288 & 58.4 & -1.0 & 2.3 & New \\
\hline $\mathrm{E} 19-\mathrm{F} 1^{(1)}$ & 84 & 09 & 3.311 & 156 & 51 & 7.542 & 83.9 & 256.2 & -383.3 & New \\
\hline $\mathrm{G} 1^{(1)}$ & 84 & 03 & 58.211 & 152 & 11 & 43.393 & 105.6 & 204.6 & -473.4 & New \\
\hline$G 2^{(2)}$ & 84 & 00 & 31.461 & 150 & 34 & 47.983 & 135.6 & 178.3 & -522.9 & New \\
\hline $\mathrm{G} 3^{(1)}$ & 83 & 25 & 33.293 & 162 & 43 & 43.009 & 22.5 & 281.1 & -33.3 & New \\
\hline $\mathrm{H} 1-\mathrm{H}_{2}^{(2)}$ & 83 & 53 & 49.241 & 150 & 25 & 27.059 & 124.1 & -10.7 & -6.8 & New \\
\hline$J 1^{(1)}$ & 83 & 35 & 18.847 & 171 & 36 & 58.078 & 28.7 & 243.9 & -264.7 & New \\
\hline$J 2^{(1)}$ & 83 & 18 & 56.544 & 173 & 5 & 29.436 & 26.7 & 263.7 & -202.8 & New \\
\hline $3^{(2)}$ & 83 & 07 & 12.527 & 174 & 56 & 17.354 & 27.7 & 324.4 & -162.7 & New \\
\hline $\mathrm{K} 1^{(1)}$ & 83 & 10 & 18.292 & 168 & 9 & 42.440 & 18.4 & 205.7 & -80.8 & New \\
\hline $\mathrm{K} 2^{(1)}$ & 82 & 56 & 29.394 & 169 & 58 & 33.135 & 10.5 & 186.2 & -98.3 & New \\
\hline $\mathrm{K} 3^{(1)}$ & 82 & 49 & 21.887 & 171 & 10 & 34.326 & -5.7 & 185.7 & -143.7 & New \\
\hline $\mathrm{L} 1^{(2)}$ & 83 & 06 & 11.551 & 172 & 25 & 19.321 & 55.2 & -0.5 & 4.0 & New \\
\hline MID-MO(1) & 84 & 17 & 42.130 & 158 & 13 & 24.896 & 71.0 & 255.2 & -397.3 & New \\
\hline W3 $3^{(2)}$ & 84 & 56 & 4.837 & 154 & 37 & 47.374 & 90.2 & -7.2 & -23.0 & New \\
\hline W5 $5^{(1)}$ & 84 & 35 & 31.426 & 166 & 37 & 33.460 & 51.0 & 256.5 & -309.8 & New \\
\hline W5513 & 84 & 57 & 40.458 & 142 & 54 & 12.483 & 236.6 & 184.4 & -83.8 & -6.5 \\
\hline W5515 & 84 & 44 & 32.806 & 146 & 12 & 45.941 & 189.0 & 201.3 & -181.5 & 8.7 \\
\hline W514 & 85 & 10 & 36.387 & 139 & 34 & 42.507 & 289.5 & 25.7 & -9.1 & 15.1 \\
\hline
\end{tabular}


results in Whillans and others (1987) did not involve these precise orbits. In the present work, absolute positions of the survey stations are accurate to about $1 \mathrm{~m}$. Relative positions for stations linked together in a network adjustment are more precise, but discussion here relates to absolute velocities, which are accurate to

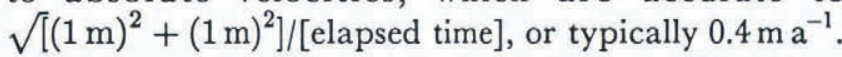

A few positions are calculated from tracking data provided by other groups. As indicated in Table 1, some of these positions are of lesser quality because fewer satellite passes were tracked. There are positions and velocities in Table 1 that lie outside the area of the figures and are not plotted.

Many stations have been surveyed three times, giving two velocity determinations. There is no significant change in velocity. Only vectors calculated from the longest time interval are presented. Positions are relative to the WGS84 ellipsoid. Heights above the geoid are about $40 \mathrm{~m}$ smaller (AUSLIG, 1980; Rapp and others, 1991).

\section{ICE STREAM B}

In drawing the boundary for the onset of ice-stream flow in Figure 3, active ice-stream flow is defined as grounded ice having a driving stress less than about $50 \mathrm{kPa}$ and speeds in excess of about $100 \mathrm{ma}^{-1}$ (expanding on a definition suggested by Bentley (1987)). Other definitions are possible but this definition emphasizes the essential anomaly of the ice streams in this vicinity (fast despite small driving stress). Other drainages, such as Rutford Ice Stream (Frolich and Doake, 1988) and Jakobshavns Isbræ (Echelmeyer and others, 1991), are not anomalous in this way and may be more like outlet glaciers.

Older maps of Ice Stream B show different positions for the boundaries of the ice stream in its upper reaches (Rose, 1979; Shabtaie and others, 1987). The earlier maps are based on correlation of sites of strong radar back-scatter and the assumption that these sites represent lateral shear margins. It appears that some of these regions with dense crevasses do not correspond to shear margins.

For appropriately averaged surface slope, velocity vectors are perpendicular to surface-elevation contours from Retzlaff and others (1993). Up-glacier of the onset region of the ice stream (stations 50 to 65), the vectors are perpendicular to slope averaged over about $15 \mathrm{~km}$ in all directions (Fig. 3). Within the ice stream, flow is perpendicular to surface slope measured over $50 \mathrm{~km}$ along-flow and across the full width within the ice-stream boundaries, excluding the inter-stream ridges. The cause of the surface-slope variations within the ice stream and the reason that they have such a small effect on ice flow is not fully understood. Whatever the cause, averages of the

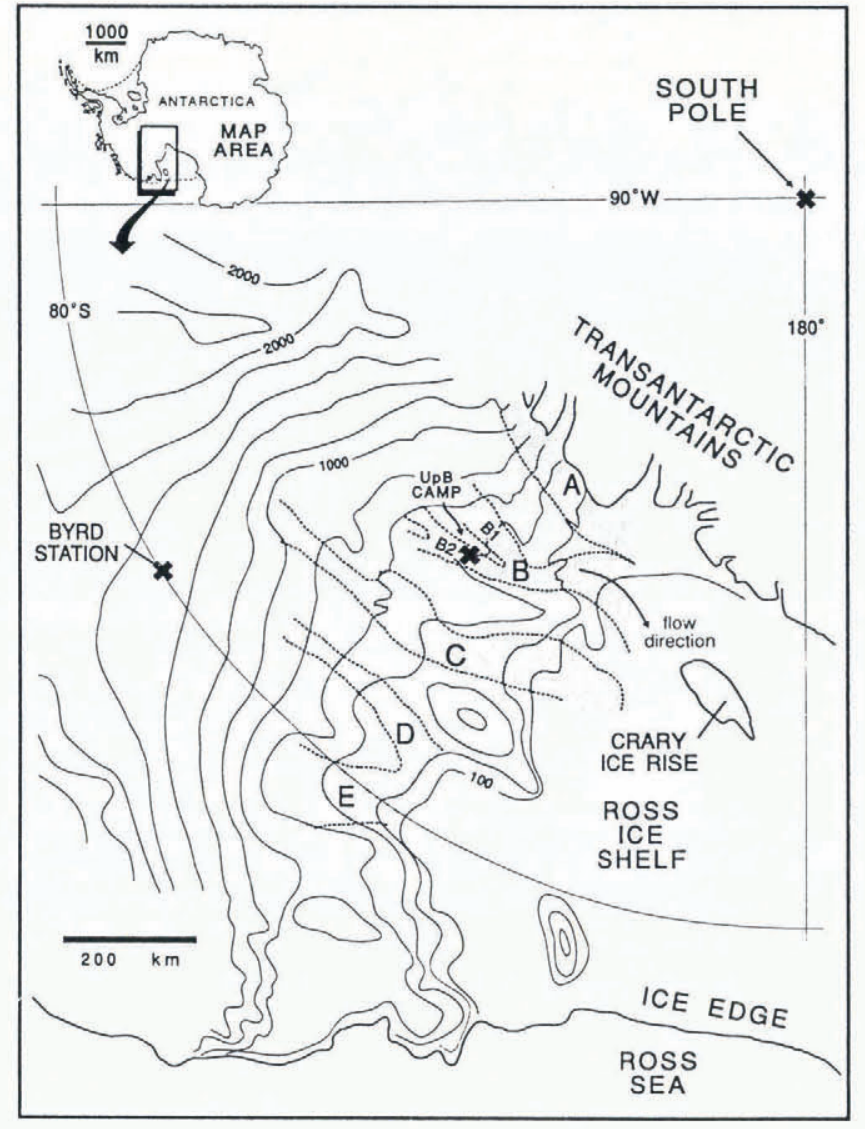

Fig. 1. Location of ice streams (indicated by STIPPLING) draining into the Ross Ice Shelf.

driving stress for ice streams must be taken over larger distances in order to correlate with flow direction.

Where Ice Stream B is well-defined, its width varies slowly. The width of tributary B2 varies by a factor of only 2 between the UpB camp and station $45,150 \mathrm{~km}$ down-glacier. The width of tributary $\mathrm{Bla}$ varies even less over the same distance. The simplicity of the form of the ice-stream margins and the lack of clear basal topographic control on many of the margins (Shabtaie and Bentley, 1988) indicates that some process, probably involving the transmission of shear stress between the inter-stream ridges and the ice stream, is determining the location and intensity of the shear margins.

In contrast to tributary $\mathrm{B} 2$ and the trunk of Ice Stream B, there is more basal relief and more important basal topographic control on the course of the subtributaries of tributary B1. Ridges $\mathrm{Bla} / \mathrm{B} 1 \mathrm{~b}$ and $\mathrm{B} 1 / \mathrm{B} 2$ (the unicorn) are associated with basal highs (Retzlaff and others, 1993). A comparison of the maps of velocity and bed elevation shows that tributary Bl tends to flow around, and not over, basal highs. The region of tributary B2 and the snake is remarkable for having little apparent bed-topographic control.

The headward onset of ice-stream flow is not marked

(1) Less precise orbits used and tracking data of poorer quality.

(2) Less precise orbits used.

Stations whose name starts with "W" were occupied by the University of Wisconsin in Madison; all other stations whose name starts with a letter (except for "UpB", "North" and "South") were occupied by NASA-GSFC. 


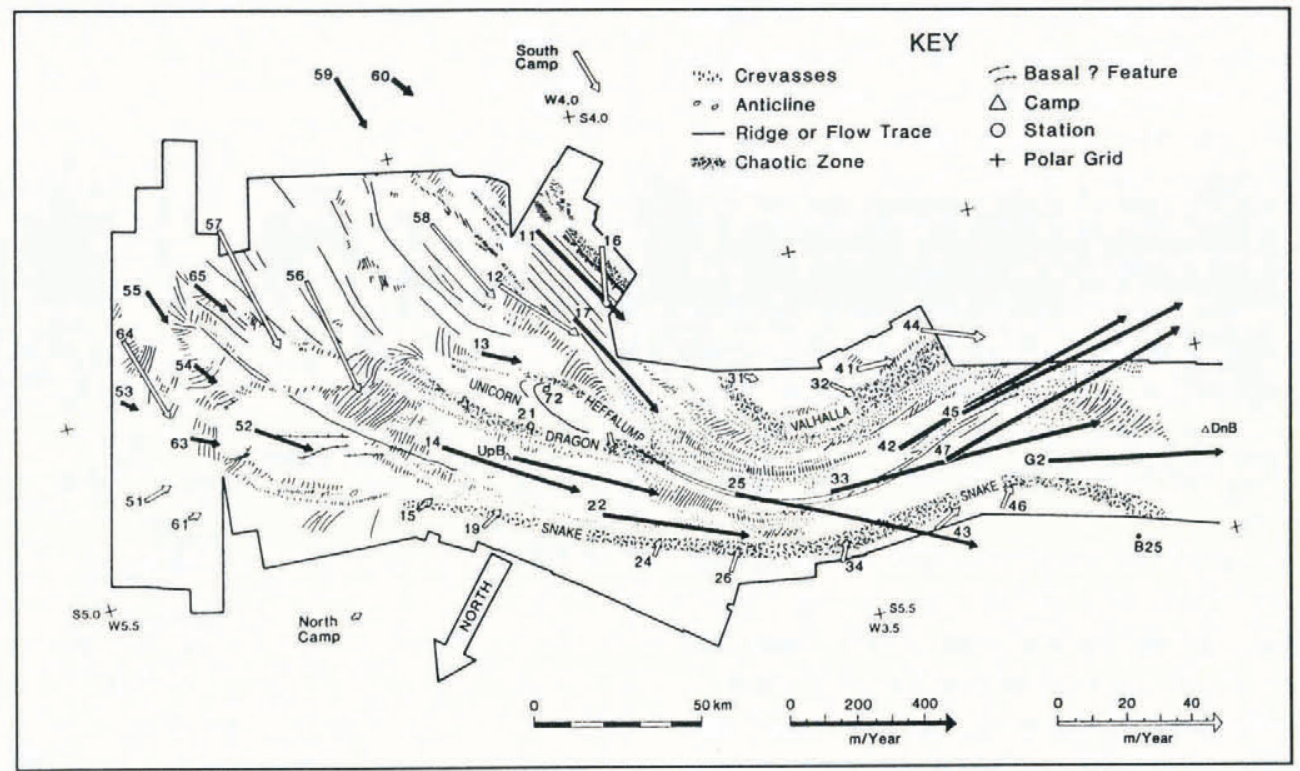

Fig. 2. Velocity vectors superimposed on a sketch of major surface features from aerial photographs and satellite images. Some polar-grid intersections are indicated to aid correlations with the maps of Retzlaff and others (1993). The anticlines (also called warps) have been discussed by Merry and Whillans (1993). The basal(?) features are surface ridges that are less simple in form than other linear features. We speculate that they are due to ice flowing over hogbacks in the bed (ends of dipping strata that resist erosion).

by a simple boundary. Rather, the boundary wanders back and forth by at least $100 \mathrm{~km}$. There is even an "island" in the ice-stream system (the unicorn). This indicates that the criterion for the onset of ice-stream flow is achieved separately at many different sites and that ice streams, once formed, tend to persist and coalesce.

The ice-stream system is changing with time. The most accurate determination of change over a large area is that of Whillans and Bindschadler (1988), who determined that output exceeds input for the Ice Stream
B drainage basin. An average thinning over the catchment basin and ice stream of $0.06 \mathrm{~m} \mathrm{a}^{-1}$ is indicated. The limit of error is $0.04 \mathrm{~m} \mathrm{a}^{-1}$. This is believed to be the most accurate way to quote errors. However, for comparison with estimates by other authors, a standard error has been calculated by taking error limits on individual measurements as equal to twice the standard error and assuming that errors tend to cancel in a statistical way. The standard error is $0.01 \mathrm{~m} \mathrm{a}^{-1}$.

Earlier studies over smaller areas show rapid thinning

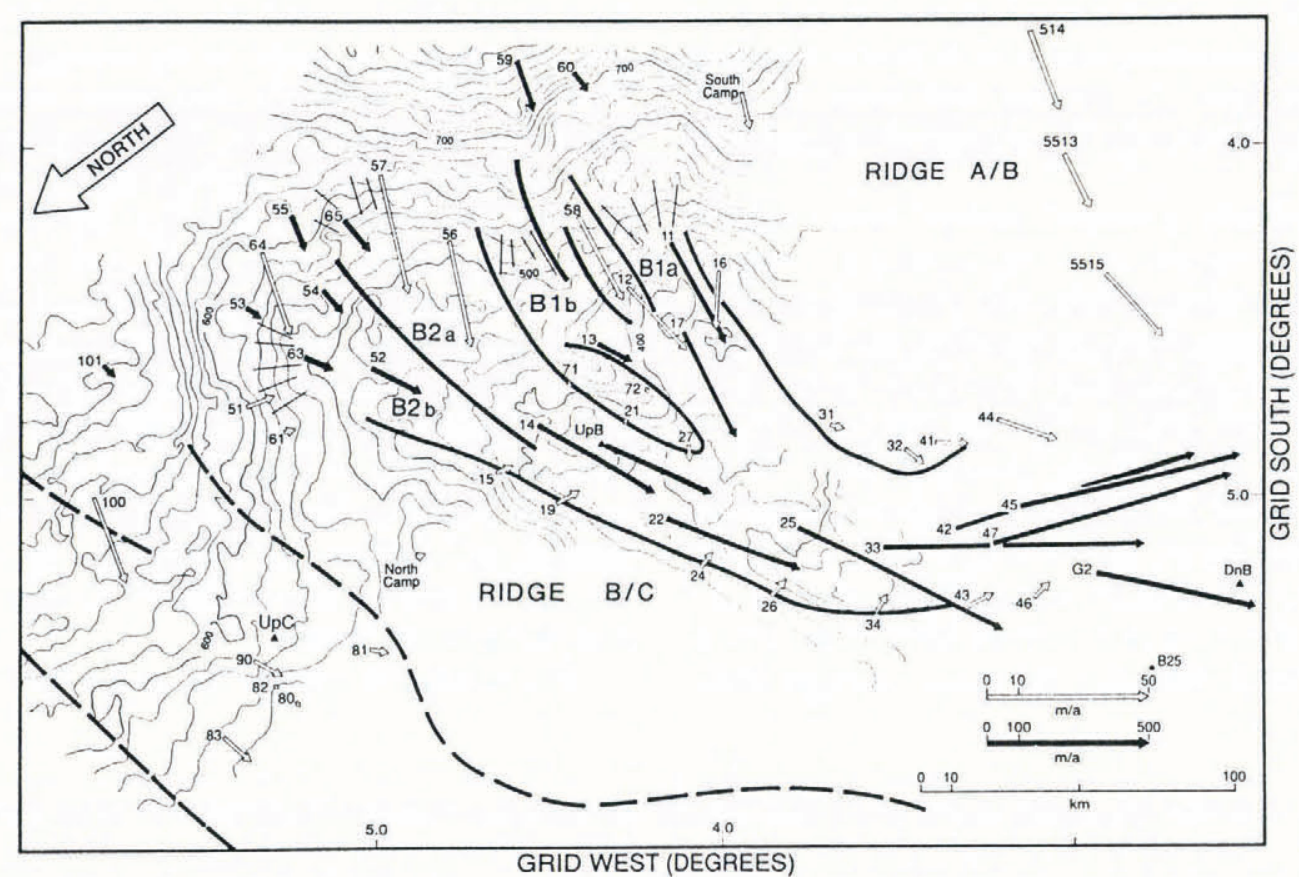

Fig. 3. Velocity vectors superimposed on elevation contours from Retzlaff and others (1993). Heavy lines mark boundaries to ice-stream flow from Merry and Whillans (1993) and Vornberger and Whillans (1990). Short lines perpendicular to contours indicate onset of ice-stream flow. 
in the upper reaches of Ice Stream B, but these results are open to re-interpretation. In their small-area calculation, Whillans and others (1987) assumed that the strain rate between velocity determinations is homogeneous, an assumption that is now clearly inappropriate in view of the complexity of tributaries shown in Figure 2. In another small-area study, Shabtaie and others (1988) used freehand interpolation to determine velocity values between measurements. Nevertheless, thinning at the icestream head and inland migration of the onset of icestream flow is an attractive process to account for the overall negative mass balance of the ice stream, the excess discharge of the ice stream being due to evacuation of ice associated with headward thinning.

\section{ICE STREAM G}

In great contrast to Ice Stream B, Ice Stream C is nearly stagnant. This confirms the early inferences. The region around the UpC camp is moving at only $1-13 \mathrm{~m} \mathrm{a}^{-1}$. Velocities in the upper reaches are about $40 \mathrm{~m} \mathrm{a}^{-1}$. The lower reach of Ice Stream C is completely stagnant (Bindschadler and others, 1988).

Velocities on Ice Stream C are inadequate to evacuate the snow-accumulation rate. For mass balance, the speed would need to be similar to that of Ice Stream B, i.e. about $400 \mathrm{~m} \mathrm{a}^{-1}$. Ice Stream $\mathrm{C}$ must now be thickening at about its snow-accumulation rate of $0.10 \mathrm{~m} \mathrm{a}^{-1}$ (Whillans and Bindschadler, 1988). The flow direction of one station (81) is inconsistent with the direction of this relict ice stream; it shows a strong component of motion toward the margin. This also indicates non-steady flow.

\section{INTER-STREAM RIDGES}

Ice flows into the sides of Ice Stream B all along its length. This flow usually enters the ice stream at an angle of about $45^{\circ}$ to the main flow and is perpendicular to elevation contours on the inter-stream ridges.

The flow of ice from inter-stream ridge $\mathrm{B} / \mathrm{C}$ is consistent with steady flow by internal creep. The discharge by internal creep using flow-law parameters from Hooke (1981) balances the up-glacier accumulation reported by Whillans and Bindschadler (1988), but limits of error would allow thinning as fast as $0.3 \mathrm{ma}^{-1}$ or thickening as fast as $0.1 \mathrm{~m} \mathrm{a}^{-1}$ (McDonald, 1990, p. 83). Within uncertainties, principally associated with the flow law and the size of the catchment area, the ridge may be in balance and flowing without basal slip.

The steadiness of flow from ridge $\mathrm{A} / \mathrm{B}$ cannot be assessed with even this level of imprecision. This is because the shape of the ridge is complex and catchment areas for the flow cannot be drawn with confidence.

Whillans and others (1987) argued that the velocity of station 27 is very anomalous. This station is at the tip of the unicorn (ridge B1/B2) and is moving across-flow. It seemed that such flow cannot be sustained by up-glacial snow accumulation and that the tip of the unicorn is being pushed by tributary $\mathrm{Bl}$ or pulled sideways by tributary B2. This led to the suggestion that there may exist rafts of stiff ice that are being carried along by the ice stream. However, a less dramatic interpretation is now possible. Elevation contours (Fig. 3) indicate that ice is routed along the long axis of the unicorn. Station 27 seems to be at a special site, just where most of the discharge from the unicorn exits. The anomaly is not so much with the velocity as it is with the unusual topographic shape of the unicorn.

\section{LONGITUDINAL TENSION AND COMPRESSION}

Along most of its length, the surface of Ice Stream B is very flat. Consequently, the driving stress is small (less than $20 \mathrm{kPa}$; Alley and Whillans, 1991, fig. 2), yet the surface speed is very large. This combination of small driving stress and large speed places active ice streams in a category transitional between inland-ice flow and iceshelf flow.

Perhaps longitudinal tension or compression is very important in countering gravity as described by the driving stress. In the models of MacAyeal (1989) and Hughes (1992), the driving stress in ice streams is taken to be partly or largely balanced by longitudinal compression (MacAyeal) or tension (Hughes). The present data, together with strain rates measured earlier on the Ross Ice Shelf (Thomas and others, 1984) can be used to evaluate longitudinal stresses and test this hypothesis.

The flowline selected for this calculation is shown in Figure 4. It begins at station 55, passes through tributary B2 and south of Crary Ice Rise and ends at station R13, close to the calving barrier. The longitudinal elevation profile, and measured surface velocity are shown in

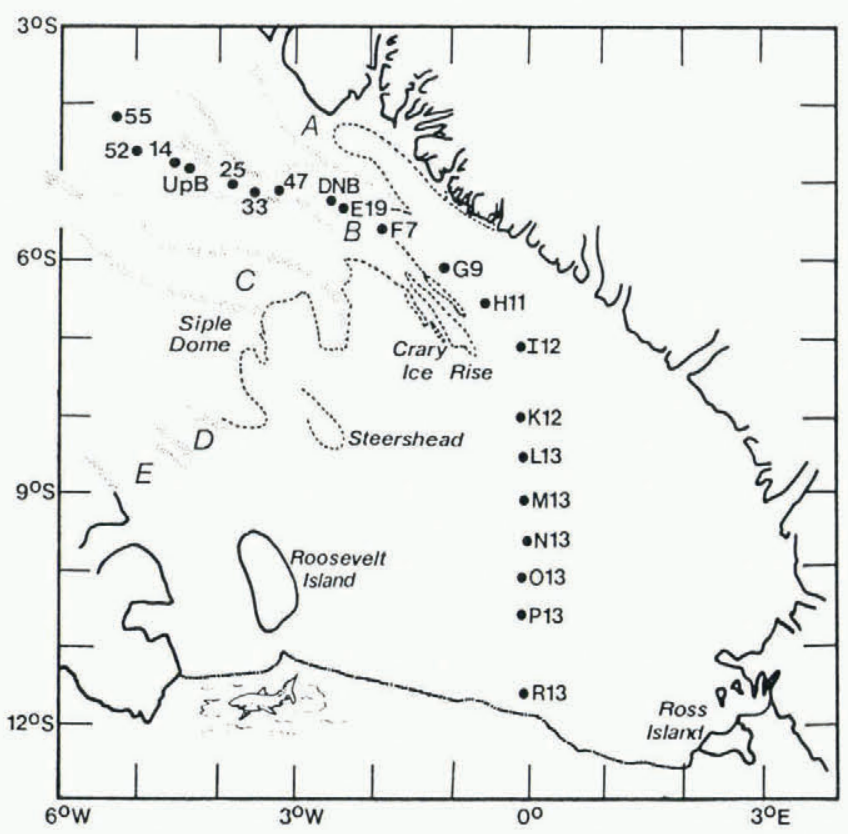

Fig. 4. Location of stations on the flowline used to calculate the role of gradients in longitudinal stress in opposing the driving stress. Marginal numbers are grid coordinates, with the Greenwich meridian as grid longitude $0^{\circ}$, and the South Pole at grid latitude $0^{\circ}$ (Bentley and others, 1979). Stippling indicates lateral shear margins. The dotted line represents the grounding line (from Shabtaie and others, 1988). 


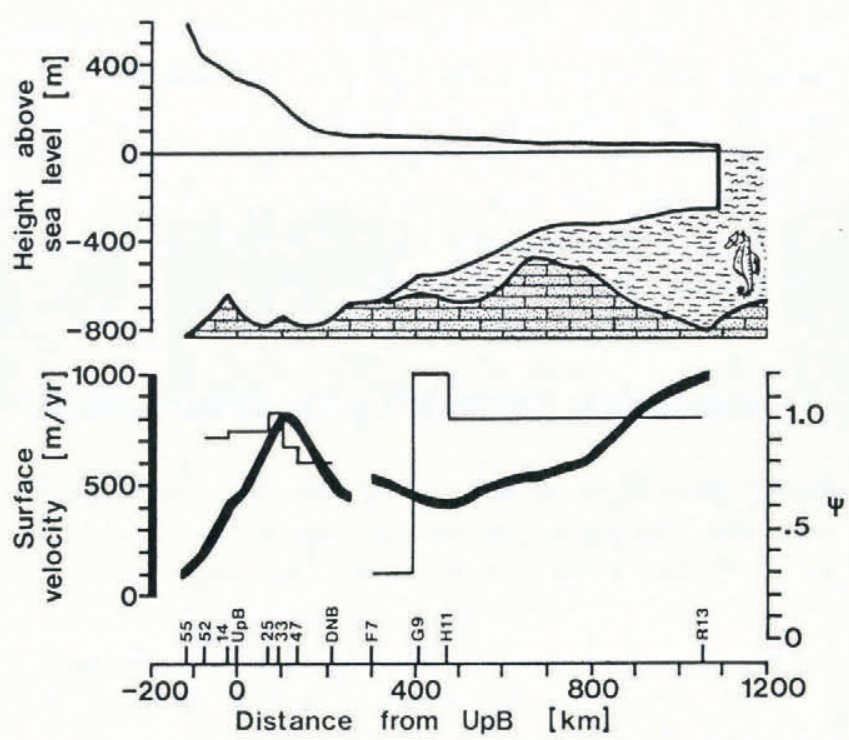

Fig. 5. Upper panel: longitudinal profile of the flowline shown in Figure 4. Lower panel: measured surface velocity (heavy curve; scale on left) and calculated fraction, $\psi$, of driving stress resisted by lateral drag and drag at the glacier base (stepped curve; scale on right).

Figure 5. Data for stations 55 through 47 are from Table 1 , and for station DNB from Bindschadler and others (1988). For stations F7 through R13, velocities and strain rates (not shown) are from Thomas and others (1984). The lines are not joined from F7 to DNB. This is because the two data sets were collected at different times, between which the velocities changed by $20 \%$ (Stephenson and Bindschadler, 1988). Ice thicknesses for the grounded stations are from Retzlaff and others (1993) and for the stations on the floating ice shelf from Bentley and others (1979).

Differential pushes and pulls (longitudinal stress gradients) are calculated from the available data as described in the Appendix. The fraction, $\psi$, of the driving stress that is opposed by lateral drag and basal drag is shown in the lower part of Figure 5 . Where $\psi=1$, all resistance to flow is due to drag at the glacier sides and bed; for $\psi=0$, longitudinal tensile or compressive gradients dominate, as would be the case if the glacier were spreading as a freely floating ice shelf (Weertman, 1957). For $\psi>1$, local basal and lateral drag support a larger part of the glacier. Figure 5 shows that longitudinal stress gradients play small roles in controling the flow of the glacier, except for the region between stations F7 and G9.

The major uncertainties in the calculations are due to measurement errors. In particular, results are sensitive to relative errors in the second spatial derivative of ice velocity. For the grounded stations, relative ice speeds are accurate to $0.2 \mathrm{~m} \mathrm{a}^{-1}$, but on the ice shelf the uncertainty is $25 \mathrm{~m} \mathrm{a}^{-1}$ or somewhat worse. Therefore, to obtain meaningful results, gradients need to be calculated over larger horizontal distances on the ice shelf than on the grounded part of the flowline.

Longitudinal stresses are generally unimportant to the force balance. Thomas and MacAyeal (1982, fig. 8) also found that the retarding force acting on the Ross Ice Shelf due to effects such as shearing past margins and the presence of ice rises is generally sufficient almost to balance the weight forces that induce ice-shelf spreading. Or, using the present notation, $\psi \approx 1$ on most of the Ross Ice Shelf.

There is a special region near station G9, between Crary Ice Rise and the Transantarctic Mountains. Compression occurs up-glacier and tension downglacier, and side drag is large; $\partial\left[H R_{x y}\right] / \partial y$ is about $0.8 \mathrm{kPa}$. Figure 5 does not depict this effect very well because side drag and driving stress are convolved. Driving stress fluctuates spatially by a large amount (from 0.9 to $0.1 \mathrm{kPa}$ ) on either side of station G9. Side drag $\left(\partial\left[H R_{x y}\right] / \partial y\right)$ more than balances the local driving stress; it supports some of the ice up- and down-glacier. The calculated amount of support depends on the values selected for the flow-law parameters but the favored values indicate support as much as $200 \mathrm{~km}$ of the glacier. This is a crucial site of large resistance, or throttle, because it controls much of the ice shelf. As has already been argued (e.g. MacAyeal and others, 1987), its mechanics are especially important. The role of this throttle is also significant because the region is changing as a large fold in the ice shelf passes (Casassa and others, 1991) and due to the progressive up-glacial migration of Crary Ice Rise (Bindschadler and others, 1989) and time changes in ice speed (Stephenson and Bindschadler, 1988).

\section{CONCLUSIONS}

The precise determinations of velocity confirm earlier work that Ice Stream B is fast and the neighboring ice is slow. The speed contrast exceeds two orders of magnitude. Ice feeds into the ice stream along most of its sides but the bulk of input occurs at the up-glacial ends of several tributaries. The lateral shear margins show no sharp bends and are remarkable for being some of the longest simple features in the ice sheet.

Some authors have suggested that longitudinal tension or compression plays a large role in holding back or pulling along the ice stream. The velocity measurements demonstrate that this is not the case; rather, the major flow resistance comes from the bed and sides for almost the entire flowline studied here. The single major exception, where longitudinal stress is important, is next to Crary Ice Rise in the ice shelf. These large stresses point to the great importance of the ice rise in controling the flow of the ice shelf.

Ice Stream C, in contrast to Ice Stream B, is confirmed to be very slowly flowing. Velocities in the upper part are similar to those in the upper part of Ice Stream B. However, the main trunk of Ice Stream C is almost stagnant.

\section{ACKNOWLEDGEMENTS}

J. McDonald did most of the calculations for positions using satellite-tracking data. G. Casassa and C. Hulbe did further calculations. This research was supported by the U.S. National Science Foundation (grant No. DPP9020760). This is Byrd Polar Research Center contribution No. 834. 


\section{REFERENCES}

Alley, R.B. and I.M. Whillans. 1991. Changes in the West Antarctic ice sheet. Science, 254(5034), 959-963.

Australian Surveying and Land Information Group. 1980. Antarctica geoid map. Second edition. Belconnen, Canberra, Department of Administration.

Bentley, C. R. 1987. Antarctic ice streams: a review. 7. Geophys. Res., 92(B9), 8843-8858.

Bentley, C. R., J. W. Clough, K. C. Jezek and S. Shabtaie. 1979. Icethickness patterns and the dynamics of the Ross Ice Shelf, Antarctica. J. Glaciol., 24(90), 287-294.

Bindschadler, R.A., S. N. Stephenson, E. P. Roberts, D. R. MacAyeal and D.R. Lindstrom. 1988. Data report for the Siple Coast Project. Washington, DC, National Aeronautics and Space Administration. (NASA Tech. Memo. 100708.)

Bindschadler, R.A., E. P. Roberts and D. R. MacAyeal. 1989. Distribution of net mass balance in the vicinity of Crary Ice Rise, Antarctica. 7. Glaciol., 35(121), 370-377.

Casassa, G., K. C. Jezek, J. Turner and I. M. Whillans. 1991. Relict flow stripes on the Ross Ice Shelf. Ann. Glaciol., 15, 132-138.

Echelmeyer, K., T.S. Clarke and W.D. Harrison. 1991. Surficial glaciology of Jakobshavns Isbræ, West Greenland: Part I. Surface morphology. J. Glaciol., 37(127), 368-382.

Frolich, R. M. and C. S. M. Doake. 1988. Relative importance of lateral and vertical shear on Rutford Ice Stream, Antarctica. Ann. Glaciol., 11, 19-22.

Hooke, R. LeB. 1981. Flow law for polycrystalline ice in glaciers: comparison of theoretical predictions, laboratory data, and field measurements. Rev. Geophys. Space Phys., 19(4), 664-672.

Hughes, T. 1992. On the pulling power of ice streams. F. Glaciol., 38(128), 125-151.

MacAyeal, D.R. 1989. Large-scale ice flow over a viscous basal sediment: theory and application to Ice stream B, Antarctica. 7 . Geophys. Res., 94(B4), 4071-4087.

MacAyeal, D. R., R.A. Bindschadler, S. Shabtaie, S. Stephenson and C. R. Bentley. 1987. Force, mass, and energy budgets of the Crary Ice Rise complex, Antarctica. 7. Glaciol., 33(114), 218-230. [Correction in F. Glaciol., 35(119), 151-152.]

McDonald, J. 1990. Use of Transit satellites to study the West Antarctic ice sheet. (M.S. thesis, Ohio State University.)

McDonald, J. and I. M. Whillans. 1988. Comparison of results from Transit satellite tracking. Ann. Glaciol., 11, 83-88.

McDonald, J. and I. M. Whillans. 1992. Search for temporal changes in the velocity of Ice Stream B, West Antarctica. J. Glaciol., 38(128), 157-161.

Merry, C.J. and I. M. Whillans. 1993. Ice-flow features on Ice Stream B, Antarctica, revealed by SPOT HRV imagery. F. Glaciol., 39(133), 515-527.

Paterson,W.S. B. 1981. The physics of glaciers. Second edition. Oxford, etc., Pergamon Press.

Rapp, R.H., Y.M. Wang and N. K. Pavlis. 1991. The Ohio State 1991 geopotential and sea surface topography harmonic coefficient models. Columbus, OH, Ohio State University. Department of Geodetic Science Survey. (Report 410.)

Retzlaff, R., N. Lord and C.R. Bentley. 1993. Airborne-radar studies: Ice Streams A, B and C, West Antarctica. F. Glaciol., 39(133), 495-506.

Rose, K.E. 1979. Characteristics of ice flow in Marie Byrd Land, Antarctica. J. Glaciol., 24(90), 63-75.

Shabtaie, S. and C.R. Bentley. 1988. Ice-thickness map of the West Antarctic ice streams by radar sounding. Ann. Glaciol., 11, 126-136.

Shabtaie, S., I. M. Whillans and C. R. Bentley. 1987. The morphology of Ice Streams A, B, and C, West Antarctica, and their environs. 7. Geophys. Res., 92(B9), 8865-8883.

Shabtaie, S., C. R. Bentley, R. A. Bindschadler and D. R. MacAyeal. 1988. Mass-balance studies of Ice Streams A, B, and C, West Antarctica, and possible surging behavior of Ice Stream B. Ann. Glaciol., 11, 137-149.

Stephenson, S.N. and R.A. Bindschadler. 1988. Observed velocity fluctuations on a major Antarctic ice stream. Nature, 334(6184), 695-697.

Thomas, R. H. and D. R. MacAyeal. 1982. Derived characteristics of the Ross Ice Shelf, Antarctica. J. Glaciol., 28(100), 397-412.

Thomas, R. H., D. R. MacAyeal, D. H. Eilers and D. R. Gaylord. 1984. Glaciological studies on the Ross Ice Shelf, Antarctica, 1973-78. Antarct. Res. Ser., 42, 21-53.

Van der Veen, C.J. and I. M. Whillans. 1989. Force budget: I. Theory and numerical methods. 7. Glaciol., 35(119), 53-60.

Vornberger, P. L. and I. M. Whillans. 1986. Surface features of Ice Stream B, Marie Byrd Land, West Antarctica. Ann. Glaciol., 8, $168-170$.

Vornberger, P. L. and I.M. Whillans. 1990. Crevasse deformation and examples from Ice Stream B, Antarctica. J. Glaciol., 36(122), 3-10.

Weertman, J. 1957. Deformation of floating ice shelves. J. Glaciol., 3(21), $38-42$.

Whillans, I. M. and R.A. Bindschadler. 1988. Mass balance of Ice Stream B, West Antarctica. Ann. Glaciol., 11, 187-193.

Whillans, I. M. and C.J. van der Veen. 1993. Patterns of calculated basal drag on Ice Streams B and C, Antarctica. 7. Glaciol., 39(133), 437-446.

Whillans, I. M., J. Bolzan and S. Shabtaie. 1987. Velocity of Ice Streams B and C, Antarctica. J. Geophys. Res., 92(B9), 8895-8902.

Whillans, I. M., M. Jackson and Y.-H. Tseng. 1993. Velocity pattern in a transect across Ice Stream B, Antarctica. F. Glaciol., 39(133), $562-572$.

The accuracy of references in the text and in this list is the responsibility of the authors, to whom queries should be addressed.

\section{APPENDIX}

To evaluate the role of longitudinal stress, consider the balance of forces in the ice-flow direction (Van der Veen and Whillans, 1989)

$$
\tau_{d x}=\tau_{b x}-\frac{\partial}{\partial y}\left[H R_{x y}\right]-\frac{\partial}{\partial x}\left[H R_{x x}\right],
$$

in which the $x$-axis is in the direction of flow and $y$ is perpendicular to it, $H$ represents ice thickness, and $R_{i j}$ are the depth-averaged components of resistive stress. This equation states that the driving stress, $\tau_{d x}$, is balanced by drag at the glacier base, $\tau_{b x}$ (which is zero for the ice shelf), lateral drag (second term on the righthand side) and gradients in longitudinal stress (third term on the righthand side).

Let $\psi$ denote the fraction of the driving stress that is opposed by basal drag and lateral drag. Then

$$
\psi=\frac{\tau_{b x}-\frac{\partial}{\partial y}\left[H R_{x y}\right]}{\tau_{d x}}
$$

and the balance equation can be written as

$$
(1-\psi) \tau_{d x}=-\frac{\partial}{\partial x}\left[H R_{x x}\right] .
$$

This equation is used to calculate $\psi$ for each position along the flowline. The driving stress is calculated from the glacier geometry, while the gradients in longitudinal stress are estimated from surface-strain rates.

The resistive stress, $R_{x x}$, is related to deviatoric stresses, $\sigma_{i j}{ }^{\prime}$ by neglecting bridging effects (Van der Veen and Whillans, 1989)

$$
R_{x x}=2 \sigma_{x x}{ }^{\prime}+\sigma_{y y}{ }^{\prime} .
$$

Invoking the constitutive relation (Paterson, 1981, p. 3031)

$$
\sigma_{i j}{ }^{\prime}=B \dot{\epsilon}_{\mathbf{e}}^{(1 / n)-1} \dot{\epsilon}_{i j}
$$

gives

$$
R_{x x}=B \dot{\epsilon}_{\mathrm{e}}^{(1 / n)-1}\left(2 \dot{\epsilon}_{x x}+\dot{\epsilon}_{y y}\right) .
$$


Here, $B$ represents the rate factor $\left(540 \mathrm{kPa} \mathrm{a}^{-\frac{1}{3}}\right.$ for $n=3$ from Whillans and Van der Veen (1993)), and $\dot{\epsilon}_{\mathrm{e}}$ is the effective strain rate.

For Ice Stream B, strain rates are calculated from the ice speeds and the width of the ice stream. Longitudinal stretching is calculated from the ice speeds in Table 1:

$$
\dot{\epsilon}_{x x}=\frac{\partial U}{\partial x} .
$$

Lateral spreading may be important where the width of the ice stream varies in the flow direction. In first approximation:

$$
\dot{\epsilon}_{y y}=\frac{U}{W} \frac{\partial W}{\partial x}
$$

where $W$ represents the width of the ice stream. Along the center line, other components of strain rate may be neglected and the effective strain rate is

$$
\dot{\epsilon}_{\mathrm{e}}{ }^{2}=\frac{1}{2}\left(\dot{\epsilon}_{x x}{ }^{2}+\dot{\epsilon}_{y y}{ }^{2}+\dot{\epsilon}_{z z}{ }^{2}\right)
$$

with

$$
\dot{\epsilon}_{z z}=-\left(\dot{\epsilon}_{x x}+\dot{\epsilon}_{y y}\right)
$$

from incompressibility. The quantities used to calculate $R_{x x}$ are measurements of ice speed and ice stream width.

For the ice shelf, strain rates and rate factors from Thomas and others (1984) are used. Also, for the ice shelf, it is easier to compute driving stress from ice thickness. Because the ice shelf is floating in ocean water, the surface elevation, $h$, is related to the total ice thickness, $H$ :

$$
h=\left[1-\frac{\rho}{\rho_{\mathrm{w}}}\right] H
$$

where $\rho$ and $\rho_{\mathrm{w}}$ denote the density of the ice shelf $\left(0.897 \mathrm{Mg} \mathrm{m}^{-3}\right)$ and sea water $\left(1.028 \mathrm{Mg} \mathrm{m}^{-3}\right.$ ) (MacAyeal and others, 1987), respectively. The driving stress is thus

$$
\begin{aligned}
\tau_{d x} & =-\rho g H \frac{\partial h}{\partial x} \\
& =-\rho g H\left[1-\frac{\rho}{\rho_{\mathrm{w}}}\right] \frac{\partial H}{\partial x} .
\end{aligned}
$$

Ice-thickness values have been taken from Bentley and others (1979). 